\title{
PERAN PUSAT PELAYANAN TERPADU SERUNI SEMARANG JAWA TENGAH DALAM MEMBERIKAN PERLINDUNGAN HUKUM BAGI ANAK KORBAN KEKERASAN DALAM RUMAH TANGGA BERBASIS NILAI KEADILAN
}

\author{
Ida Musofiana \\ Dosen Fakultas Hukum Unissula \\ ida.musofiana@unissula.ac.id
}

\begin{abstract}
This paper aims to assess the role of Integrated Servis Center Seruni Semarang Central Java. This study is included in the sociological juridical study, as the researcher conducts the the research by going directly to the field. The conseptual framework starts with the theory justice, for children who are victims domestic violence. Primary data sources consist of field research results, while secondary data are references to bibliography related to legal protection for child victims and related legislation. While data analysis using content analysis. The results showed that children who were subjected to violence in police handling were handled by the Woman and Child Protection Unit, but the police could refer or sent child victims to Semarang Integrated Hospital or Service Center for those domiciled in Semarang.for a child who feel trheatened his soul then lead the victim to a safe house. Integrated Service Center Seruni Semarang Central Java performs its duties in accordance with the Dercree Mayor of Semarang No.463/05/2011 on the Establishment of Integrated Service Team on Handling Violence Againts Women and Children Based on Gender "SERUNI" Semarang City Central Java.
\end{abstract}

Keywords : integrated service center role, child protection, victim.

\begin{abstract}
Abstrak
Tulisan ini bertujuan untuk mengkaji peran dari Pusat Pelayanan Terpadu Seruni Semarang Jawa Tengah. Kajian ini termasuk dalam kajian yuridis sosiologis, karena peneliti melakukan penelitian dengan terjuan langsung ke lapangan. Kerangka konsepnya berawal dari teori keadilan, bagi anak yang menjadi korban kekerasan dalam rumah tangga. Sumber data primer terdiri dari hasil penelitian lapangan, sedangkan data sekunder berupa referensi kepustakaan yang berhubungan dengan perlindungan hukum bagi anak korban serta perundang-undangan yang terkait. Sedangkan analisis data menggunakan analisis isi (content analysis). Hasilnya menunjukkan bahwa anak yang mendapat kekerasan dalam penanganan kepolisian ditangani oleh Unit Perlindungan Perempuan dan Anak, namun kepolisian dapat merujuk/mengirimkan anak korban ke Rumah Sakit atau Pusat Pelayanan Terpadu Seruni Semarang bagi yang berdomisili daerah Semarang. Bagi anak yang merasa terancam jiwanya maka mengantar korban ke rumah aman. Pusat Pelayanan Terpadu Seruni Semarang Jawa Tengah melaksanakan tugas sesuai dengan Surat Keputusan Wali Kota Semarang No.463/05/2011 tentang Pembentukan Tim Pelayanan Terpadu Penanganan Kekerasan Terhadap Perempuan dan Anak yang Berbasis Gender "SERUNI" Kota Semarang Jawa Tengah.
\end{abstract}

Kata kunci : peran pusat pelayanan terpadu, perlindungan anak, korban. 


\section{A. Pendahuluan}

Anak merupakan amanah sekaligus karunia Tuhan Yang Maha Esa, yang senantiasa harus kita jaga karena dalam dirinya melekat harkat, martabat, dan hak-hak sebagai manusia yang harus dijunjung tinggi. Hak asasi anak merupakan hak asasi manusia yang termuat dalam UndangUndang Dasar 1945 dan Konvensi Perserikatan Bangsa-Bangsa. ${ }^{1}$ Melakukan kajian terhadap anak sangatlah menarik, mengingat anak adalah penerus cita-cita bagi kemajuan suatu bangsa. Di dalam diri seorang anak memiliki sifat dan ciri khusus, yaitu secara fisik maupun mental belum memiliki kemampuan untuk berdiri sendiri sehingga anak memerlukan perlindungan dalam rangka menjamin pertumbuhan dan perkembangan secara utuh dan serasi dalam kehidupannya.

Diakuiataupun tidak, dalam masa pertumbuhan secara fisik dan mental, anak membutuhkan perawatan, pendidikan, serta pelindungan hukum baik sebelum mapun sesudah lahir. Agar setiap anak mampu memikul tanggung jawab sebagai penerus bangsa, anak perlu mendapat kesempatan seluas-luasnya secara optimal baik fisik, mental, mapun sosial. Patut diakui bahwa keluarga merupakan lingkungan alami bagi pertumbuhan dan kesejahteraan anak. Perkembangan kepribadian anak secara utuh dan serasi membutuhkan keluarga yang bahagia, pengertian dan penuh kasih sayang dari lingkungannya.

Perlindungan anak merupakan usaha dan kegiatan seluruh lapisan masyarakat dalam berbagai kedudukan dan peranan, yang menyadari betul pentingnya anak bagi nusa dan bangsa di kemudian hari. Jika mereka telah matang pertumbuhan fisik maupun mental dan sosialnya, maka tiba saatnya menggantikan generasi terdahulu. ${ }^{2}$ Masalah perlindungan hukum dan hak-haknya bagi anak-anak merupakan salah satu sisi pendekatan untuk melindungi anakanak Indonesia. Agar perlindungan hak-hak anak dapat dilakukan secara teratur, tertib dan bertanggung jawab maka diperlukan peraturan

1 Penjelasan Ketentuan Umum Undang-Undang Nomor 23 Tahun 2002 tentang Perlindungan Anak.

2 Maidin Gultom, 2006, Perlindungan Hukum Terhadap Anak (Dalam Sistem Peradilan Pidana Anak di Indonesia), Refika Aditama, Bandung, hlm. 33. hukum yang selaras dengan perkembangan masyarakat Indonesia yang dijiwai sepenuhnya oleh Pancasila dan Undang-Undang Dasar 1945.

Persoalan perlindungan hukum bagi anakanak, Undang-Undang Dasar 1945 amandemen keempat Pasal 28 B ayat (2) telah ditegaskan bahwa "Setiap anak berhak atas kelangsungan hidup, tumbuh dan berkembang serta berhak atas perlindungan dari kekerasan dan diskriminasi". Serta dalam Pasal 34 ayat (1) UUD 1945 bahwa "Fakir miskin dan anak-anak terlantar dipelihara oleh negara". Indonesia merupakan salah satu negara yang telah meratifikasi Konvensi Hak-hak Anak PBB melalui Keputusan Presiden Nomor 36 Tahun 1990, dengan demikian menyatakan keterkaitannya untuk menghormati dan menjamin hak anak tanpa diskriminasi dalam wilayah hukum Republik Indonesia. Melalui Undang-Undang Nomor 23 Tahun 2002 tentang Perlindungan Anak dimana undang-undang ini memberikan perlindungan hukum kepada anak terhadap segala bentuk kekerasan, dan diskriminasi termasuk melindungi anak yang menjadi korban tindak pidana. Namun pada kenyataannya masih banyak anak yang dilanggar haknya, dan menjadi korban dari beberapa bentuk tindak kekerasan, perlakuan salah, bahkan tindakan tidak manusiawi terhadap anak, tanpa ia dapat melindungi dirinya.

Dewasa ini kejahatan yang menimpa terhadap anak sering terjadi dan muncul diberbagai media, dan ironisnya pelaku kejahatan tersebut dilakukan oleh orang terdekat mereka, baik oleh guru, tetangga, paman, sepupu, kakek, ayah tiri bahkan ayah atau ibu kandung sendiri. Maraknya pemberitaan kekerasan terhadap anak yang semakin meningkat, mendorong untuk meneliti permasalahan perlindungan hukum terhadap anak, bentuk upaya hukum anak sebagai korban kekerasan dalam rumah tangga, serta peranan pemerintah dan pihakpihak yang terkait dalam perlindungan hukum bagi anak korban kekerasan.

Melihat kenyataan di atas, lalu timbul pertanyaan bahwa sudah semestinya rasa kemanusiaan kita timbul untuk memberikan perhatian kepada anak yang menjadi korban, terlebih khusus anak yang menjadi korban 
kekerasan dalam rumah tangga. Di lingkungan kepolisian ada unit khusus yang memberikan perlindungan hukum kepada anak yang menjadi korban tindak pidana termasuk di dalamnya korban kekerasan dalam rumah tangga. Apabila anak yang menjadi korban membutuhkan lebih perhatian seperti mendapatkan rumah aman, pihak kepolisian bisa berkoordinasi dengan pihak Pusat Pelayanan Terpadu Seruni Semarang Jawa Tengah. Bagaimanakah peran Pusat Pelayanan Terpadu Seruni Semarang Jawa Tengah dalam memberikan perlindungan hukum terhadap anak yang menjadi korban kekerasan dalam rumah tangga?

Dalam penelitian ini dipergunakan metode Yuridis Sosiologis atau Social Legal Research, penelitian dilakukan dengan meninjau dari peraturan-peraturan tertulis yang sudah ada untuk pemecahan yang khusus dilakukan atas pengetahuan yang didapat terlebih dahulu oleh peneliti penelitian atau terjun ke masyarakat, sehingga lebih menjamin adanya kepastian hukum yang sesuai dengan rasa keadilan dan rasa kebutuhan hukum yang hidup di dalam masyarakat. Pendekatan yuridis digunakan dalam usaha mengalisis data dengan mengacu pada norma-norma hukum yang dituangkan dalam peraturan perundang-undangan, sedangkan aspek sosiologis dari penelitian ini adalah terjun ke lokasi penelitian untuk mengetahui bentuk dan pelaksanaan dalam perlindungan hukum bagi anak korban tindak pidana oleh Pusat Pelayanan Terpadu Seruni Semarang Jawa Tengah. Kedua aspek tersebut oleh peneliti kemudian diteliti dan dianalisa dalam praktek pelaksanaannya di Pusat Pelayanan Terpadu Semarang Jawa Tengah.

Dalam penelitian ini dipergunakan metode penelitian DeskriptifAnalisis, sebab peneliti dalam menganalisis berkeinginan untuk memberikan gambaran atau pemaparan atas objek yang menjadi pokok permasalahan. Objek yang dimaksud di sini yaitu tentang bentuk dan pelaksanaan perlindungan bagi anak korban tindak pidana Pusat Pelayanan Terpadu Semarang dan kendala-kendala dalam pemberian perlindungan hukum bagi anak korban kekerasan dalam rumah tangga oleh Pusat pelayanan Terpadu Semarang.

\section{B. Hasil Penelitian dan Pembahasan}

1. Perlindungan Hukum terhadap korban

Pentingnya perlindungan terhadap korban tindak pidana, korban mempunyai hak kepentingnnya dilindungi oleh negara. Barda Nawawi Arief ${ }^{3}$ menyebutkan bahwa pengertian perlindungan korban tindak pidana dapat dilihat dari dua macam makna, yaitu :

a. Perlindungan hukum untuk tidak menjadi korban tindak pidana yang berarti perlindungan hak asasi manusia atau kepentingan hukum seseorang.

b. Perlindungan hukum untuk memperoleh jaminan atau santunan hukum atas penderitaan/kerugian orang yang telah menjadi korban tindak pidana. Bentuk santunan itu dapat berupa pemulihan nama baik (rehabilitasi), pemulihan keseimbangan batin (antara lain dengan pemaafan), pemberian ganti kerugian (restitusi, kompensasi, jaminan/santunan kesejahteraan sosial).

Menurut Komisi Perlindungan Anak terdapat beberapa jenis hak perelindungan anak yang perlu didukung :

a. Perlindungan untuk semua anak diantaranya dilindungi dari keadaan tidak harmonis dalam keluarga, dilindungi milik dan rahasia pribadinya, dilindungi hak hidupnya dan pemenuhan kebutuhan dasarnya, dilindungi agar tidak putus sekolah, dilindungi dari haknya untuk bermain dan berkumpul dengan teman sebayanya;

b. Perlindungan untuk anak yang dalam keadaan sulit, atau anak-anak yang mengalami perlakuan buruk, yaitu dengan melindunginya dari tindakan kekerasan, anak yatim piatu atau tanpa keluarga harus dilindungi dengan cara ditempatkan pada yayasan atau adopsi, perempuan

Barda Nawawi Arief Dalam Lilik Mulyadi, 2008, Bunga Rampai Hukum Pidana Dalam Perspektis Teoritis dan Praktek, PT. Alumni, Bandung, hlm. 250 
muda atau istri yang medapat pemukulan atau tindak kekerasan dari suaminya, anak cacat dilindungi hak miliknya sebagaimana anak yang lain pada umumnya, anak dalam situasi perang atau pengungsian korban penculikan dilindungi secara khusus oleh Negara. ${ }^{4}$

Pengkajian terhadap eksistensi korban sangatlah penting, dalam rangka meninjau hubungan korban dengan pelaku (victims offenders relationship) untuk kepentingan proses peradilan pidana dalam rangka pertanggungjawaban pelaku, juga dalam rangka menetapkan bentuk dan besarnya kompensasi dan/atau restitusi yang akan diterima oleh korban. Hal ini juga dimaksudkan sebagai sumbangan informasi bagi pihak yang berwenang dalam rangka menetapkan kebijakan penanggulangan kejahatan yang berpijak dari sudut korban.

Perlindungan hukum terhadap korban tindak pidana. Perlindungan hak-hak korban dilihat dari beberapa teori, diantaranya adalah: ${ }^{5}$

\section{a. Teori Utilitas}

Teori ini menitik beratkan pada kemanfaatan terbesar bagi jumlah yang besar. Konsep pemberian perlindungan bagi korban dapat dilaksanakan sejauh memberi kemanfaatan yang lebih besar dari pada tidak diterapkannya konsep tersebut, tidak saja bagi korban tetapi juga pada sistem penegakan hukum pidana secara keseluruhan.

b. Teori Tanggung jawab

Subyek hukum pada dasarnya harus mempertanggungjawabkan segala perbuatan hukum yang dilakukannya sehingga apabila seseorang melakukan tindak pidana yang menyebabkan orang lain menderita kerugian maka harus

4 Erika, 2004, Perlindungan Hukum Terhadap Anak Dalam Kasus Kekerasan yang Dialami Oleh Anak ditinjau Dari Undang-Undang Nomor 23 Tahun 2002 tentang Perlindungan Anak, UNIKA Atmajaya, Jakarta, hlm. 70

5 Didik M. Arief Mansur dan Elisatris Gultom, 2008, Urgensi Perlindungan Korban Kejahatan, PT Raja Grafindo, Jakarta, hlm. 163. bertanggungjawab atas kerugian yang ditimbulkannya.

c. Teori Ganti Kerugian

Sebagai bentuk tanggung jawab atas kesalahannya pada orang lain maka pelaku tindak pidana dibebani kewajiban untuk memberikan ganti rugi pada korban atau ahli warisnya.

Selain teori-teori perlindungan korban ada juga asas-asas yang harus ada di dalam hukum pidana materiil, hukum pidana formil maupun dalam hukum pelaksanaan pidana. Asas-asas yang dimaksud adalah : 6

\section{a. Asas Manfaat}

Perlindungan korban tidak hanya untuk tercapainya kemanfaatan materiil maupun spiritual bagi korban saja yang melainkan juga untuk kemanfaatan bagi masyarakat luas, khususnya sebagai upaya mengurangi jumlah tindak pidana serta menciptakan ketertiban dalam masyarakat.

b. Asas Keadilan

Penerapan asas keadilan dalam upaya menganggulangi kejahatan tidak mutlak perhatian pada pelaku saja karena harus dibatasi juga dengan keadilan yang harus diberikan kepada korban.

c. Asas Keseimbangan

Tujuan hukum tidak hanya kepastian dan perlindungan hukum bagi manusia tetapi juga untuk memulihkan keseimbangan menuju kepada keadaan semula, asas keseimbangan memiliki tempat yang penting dalam upaya pemulihan hak-hak korban.

\section{Kekerasan Dalam Rumah Tangga}

Menurut Pasal 1 dari Undang-Undang

No. 23 Tahun 2004 tentang Penghapusan Kekerasan dalam Rumah Tangga (PKDRT), kekerasan adalah setiap perbuatan terhadap seseorang terutama perempuan, yang berkaitan timbulnya kesengsaraan atau penderitaan secara fisik, seksual, psikologis, dan/atau penelantaran rumah tangga termasuk ancaman untuk melakukan

6 Arief Gosita, 1989, Hukum Perlindungan Anak, Akademika Pressindo, Jakarta, hlm. 50. 
perbuatan, pemaksaaan, atau perampasan kemerdekaan secara melawan hukum dalam lingkup rumah tangga. Sedangkan rumah tangga menurut Kamus Besar Bahasa Indonesia (KBBI) adalah sesuatu yang berkenaan dengan kehidupan keluarga dalam rumah. Sehingga dapat dinyatakan bahwa kekerasan dalam rumah tangga adalah suatu perlakuan yang dialami oleh sebuah keluarga sehingga menimbulkan potensi korban tidak berkembang.

Menurut Hasbianto bahwa kekerasan dalam rumah tangga adalah suatu bentuk penganiayaan secara fisik maupun emosional atau psikologis, yang merupakan suatu cara pengontrolan terhadap pasangan dalam kehidupan rumah tangga ${ }^{7}$ Menurut Pasal 1 dari Undang-Undang No. 23 Tahun 2004 tentang Penghapusan Kekerasan dalam Rumah Tangga (PKDRT), penghapusan Kekerasan dalam Rumah Tangga adalah jaminan yang diberikan oleh negara untuk mencegah terjadinya kekerasan dalam rumah tangga, menindak pelaku kekerasan dalam rumah tangga dan melindungi korban kekerasan dalam rumah tangga.

Lingkup rumah tangga sesuai UndangUndang Nomor 23 Tahun 2004 tentang Penghapusan Kekerasan Dalam Rumah Tangga, meliputi:

1. Suami, istri, dan anak;

2. Orang-orang yang mempunyai hubungan keluarga dengan orang sebagaimana dimaksud, karena hubungan darah, perkawinan, persusuan, pengasuhan dan perwalian yang menetap dalam rumah tangga;

3. Orang yang bekerja membantu rumah tangga dan menetap dalam rumah tangga tersebut. Dimana orang yang bekerja sebagaimana dimaksud dalam kalimat sebelumnya adalah dipandang sebagai anggota keluarga dalam jangka waktu selama berada dalam rumah tangga yang bersangkutan.

Sugihastuti, 2007,Teori Apresiasi Sastra, Pustaka Pelajar, Yogyakarta, hlm. 173.

\section{Anak yang Menjadi Korban}

Sesuai dengan Pasal 20 Undang-Undang Nomor 35 Tahun 2014 tentang Perubahan Atas Undang-Undang Nomor 23 Tahun 2002 tentang Perelindungan Anak:

"Negara, Pemerintah, Pemerintah Daerah, Masyarakat, Keluarga, Orangtua atau Wali berkewajiban dan bertanggung jawab terhadap penyelenggaraan Perlindungan Anak". Makna pasal tersebut jelas bahwa upaya pemenuhan dan perlindungan terhadap anak merupakan tanggung jawab bersama seluruh lapisan masyarakat yang harus mendapat dukungan dari pemerintah sepenuhnya.

Adapun kewajiban dan tanggung jawab negara dan pemerintah dalam usaha perlindungan anak diatur dalam Pasal 21 sampai dengan Pasal 25 Undang-Undang Nomor 35 Tahun 2014 tentang Perubahan Atas Undang-Undang Nomor 23 Tahun 2002 tentang Perlindungan Anak, yaitu:

a. Negara, pemerintah, dan pemerintah daerah bertanggung jawab dan menghormati pemenuhan hak anak tanpa membedakan ras, suku, agama, golongan, jenis kelamin, etnik, dan bahasa, status hukum anak, urutan kelahiran anak, kondisi fisik dan/atau mental; terdapat dalam Pasal 21)

b. Memberikan dukungan sarana dan prasarana dalam penyelenggaraan perlindungan anak; (terdapat dalam Pasal 22)

c. Menjaminperlindungan, pemeliharaan, kesejahteraan anak dengan memperhatikan hak dan kewajiban orangtua, wali atau orang lain yang secara hukum bertanggung jawab terhadap anak; (terdapat dalam Pasal 23)

d. Menjamin anakuntukmempergunakan haknya dalam menyampaikan pendapat sesuai dengan usia dan kecerdasan anak; (terdapat dalam Pasal 24)

e. Kewajiban dan tanggung jawab masyarakat dalam perlindungan terhadap anak dilaksanakan melalui kegiatan Peran masyarakat dalam 
penyelenggaraan Perlindungan

Anak dengan melibatkan organisasi kemasyarakatan, akademisi, dan pemerhati anak. (terdapat dalam Pasal 25).

\section{Peran Pusat Pelayanan Terpadu Seruni}

Pusat Pelayanan Terpadu (PPT) Seruni Semarang Jawa Tengah dibentuk dengan Surat Keputusan (SK) Walikota Semarang. Penetapan SK Walikota Semarang Nomor : 463.05/112 tanggal 4 Mei 2005 tentang Pembentukan Tim Pelayanan Terpadu Penanganan Kekerasan Terhadap Perempuan dan Anak yang berbasis Gender "SERUNl" Kota Semarang, dan dikukuhkan oleh Bapak Walikota Semarang pada tanggal $20 \mathrm{Mei}$ 2005. Tahun 2009 Surat Keputusan tersebut telah diperbaharui karena banyak anggota Tim yang Purna Tugas, sehingga Surat Keputusan Walikota tentang Pembentukan Tim Pelayanan Terpadu bagi Perempuan dan Anak yang Berbasis Gender "SERUNI" Kota Semarang telah diganti dengan Surat Keputusan No.463/A. 023 tanggal 12 Pebruari 2009. Tahun 2011 Surat Keputusan Walikota tentang Pembentukan Tim Pelayanan Terpadu bagi Perempuan dan Anak yang Berbasis Gender "SERUNI" Kota Semarang Jawa Tengah telah diganti lagi dengan Surat Keputusan Walikota Semarang tanggal 6 Januari 2011 No. 463/05/2011.

Korban yang merasa terancam jiwanya maka anggota Unit Perlindungan Perempuan dan Anak (PPA) Polrestabes Semarang akan mengantar korban ke rumah aman yang untuk sementara ini masih bergabung dengan Pusat Pelayanan Terpadu (PPT) Seruni Semarang Jawa Tengah dengan menyerahkan surat permohonan bantuan perlindungan rumah aman untuk korban kekerasan. ${ }^{8}$ Rumah aman adalah tempat yang harus dirahasiakan kepada siapa saja dan berpindah-pindah. Manfaat dari rumah aman itu sendiri yaitu layanan bagi anak yang memerlukan perlindungan khusus serta

8 Wawancara dengan Brigadir Septri kartikawti, S.H. Anggota Unit PPA Sat Reskrim Polrestabes Semarang, 26 Agustus 2016 pukul 12.45WIB memulihkan kondisi fisik, mental dan sosial yang terganggu akibat tekanan dan/atau trauma. Biasanya anak korban pencabulan, persetubuhan (korban kejahatan seksual) tidak di tempatkan di Shelter (rumah aman) akan tetapi diberikan pendampingan untuk memulihkan kondisi mental atas apa yang dialaminya.

Sesuai dengan Surat Keputusan Wali Kota Semarang No.463/05/2011 tentang Pembentukan Tim Pelayanan Terpadu Penanganan Kekerasan Terhadap Perempuan dan Anak yang Berbasis Gender "SERUNI" Kota Semarang. Prosedur penanganan anak sebagai korban tindak pidana adalah sebagai berikut :

SISTEM DAN MEKANISME PUSAT PELAYANAN TERPADU "SERUNI" (Semarang terpadu Rumah perlindungan untuk membangun nurani dan cinta kasih InsaNI)

Bagan.1.

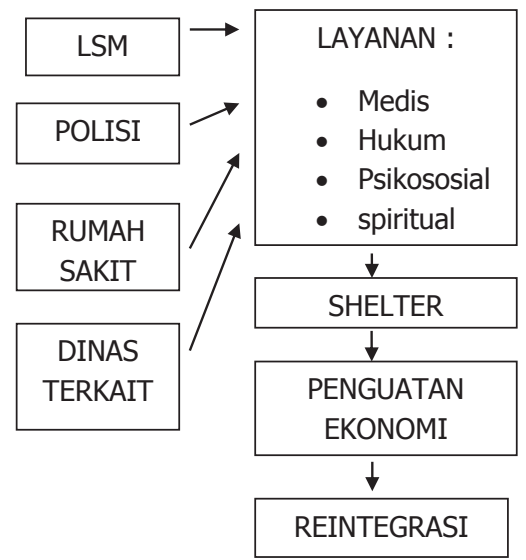

Sumber : Bagan sistem dan mekanisme Pelayanan di PPT Seruni

Klien (pihak korban) bisa datang dari pihak Lembaga Swadaya Masayarakat (LSM), kepolisian, rumah sakit maupun dinas terkait, bisa juga datang langsung ke Pusat Pelayanan Terpadu (PPT) PPT Seruni. Setelah sesampainya di PPT Seruni dianalisa apa yang menjadi kebutuhan korban, apabila korban sangat membutuhkan perlindungan rasa aman atas apa yang telah dialami dan diperlukan rumah aman/shelter, maka si korban di tempatkan di dalam shelter. Penguatan ekonomi ditujukan untuk korban 
yang kurang mampu, mengenai biaya di ajukan ke dinas sosial terkait, dan tahap reintegrasi setelah perbuatan hukum untuk bisa kembali pulih.

Perlindungan terhadap anak terutama karena mengalami kekerasan yang terjadi di dalam lingkup keluarga/rumah tangga, biasanya mengalami trauma mendalam karena keluarga adalah yang seharusnya sebagai tempat awal mendapat perhatian, kasih sayang, akan tetapi malah sebaliknya. Seperti halnya trauma dalam situasi khusus salah satunya adalah anak yang mengalami kasus kekerasan seksual, Pusat Pelayanan Terpadu Seruni Kota Semarang Jawa Tengah melakukan pengembangan guna terus mendorong terwujudnya pengembangan sistem layanan terpadu yang akan diberikan oleh instansi atau lembaga yang menjadi anggota. Pada tahun 2016, Rumah Sakit Umum Daerah Kota Semarang sebagai salah satu anggota yang berhasil mempunyai kebijakan bahwa pelayanan medis untuk perempuan dan anak Kota Semarang diberikan dengan tidak dipungut biaya. Dalam hal pengembangan kapasitas internal PPT Seruni membuka kelas setiap hari Jum'at untuk petugas penuh waktunya (full timer) dan full timer PPT Kecamatan Semarang. Dalam kelas tersebut para pendamping korban belajar tentang perspektif dan regulasi yang digunakan untuk pendampingan korban.

Pusat Pelayanan Terpadu Seruni Semarang membuka diri untuk melayani mahasiswa atau masyarakat yang akan melakukan penelitian yang mendukung untuk penghapusan kekerasan terhadap perempuan dan anak. Selain hal tersebut, PPT Seruni juga menjadi tempat mahasiswa magang untuk belajar kondisi empiris di lapangan.

Berdasarkan keterangan di atas, penulis menganalisa bahwa apabila ditelaah secara teoritis bentuk dan pelaksanaan perlindungan hukum bagi anak korban kekerasan dalam rumah tangga di PPT Seruni Semarang, sudah sesuai dengan teori tanggung jawab, melaksanakan apa yang menjadi tugas PPT Seruni sesuai dengan yang tertuang dalam Surat Keputusan Wali Kota Semarang No. 463/05/2011. Pada tahap di PPT Seruni Semarang, asas manfaat, asas keadilan dan asas keseimbangan, sudah terpenuhi. Penulis berpendapat seperti ini karena pada tahap ini PPT Seruni berupaya memberikan apa yang sekiranya dibutuhkan/diperlukan korban. Teori tanggung jawab belum sepenuhnya, karena teori tanggung jawab di sini ditujukan kepada pelaku untuk mempertanggung jawabkan atas perbuatannya. Akan tetapi, pihak PPT Seruni sudah menjalankan apa yang menjadi tugas kewajiban sebagai tim yang memiliki tugas pendampingan untuk mendampingi pihak korban mengenai apa yang telah dilaporkan oleh korban.

Asas keadilan dan manfaat terlihat saat PPT Seruni Semarang selain mendampingi juga memberikan penyuluhan mengenai perundang-undangan yang berlaku untuk menjerat pelaku, pihak korban juga diperhatikan dengan memberikan pelayanan berupa pelayanan psikis (apabila diperlukan) dengan mengarahkan untuk di bawa ke psikiater di Rumah Sakit Elisabeth atau dengan psikiater yang telah ada di Pusat Pelayanan Terpadu (PPT) Seruni Semarang. Asas keseimbangan terlihat jelas, selain menegakkan keadilan bagi korban dengan menindak pelaku, juga memberikan perhatian (apa yang dibutuhkan) kepada korban. Sedangkan teori ganti kerugian tidak terdapat pada tahap di PPT Seruni. Akan tetapi. Teori utilitas pada tahap di PPT Seruni ada, yaitu dengan adanya sasaran bagi korban untuk diberikan intensif konseling lanjutan atau rehabilitasi sosial. Hal ini sangatlah membantu bagi korban untuk kembali bersosialisasi dengan yang masyarakat lainnya.

\section{Penutup}

\section{Kesimpulan}

Perlindungan terhadap anak korban kekerasan dalam rumah tangga di Pusat Pelayanan Terpadu Seruni Kota Semarang, yang pelakunya dalam lingkup keluarga (anggota keluarga) di tempatkan di Shelter (rumah aman) dan diberikan pendampingan 
untuk memulihkan kondisi mental atas apa yang dialaminya. Pendampingan ini dilakukan mulai dari adanya laporan di PPT Seruni sampai dengan dikeluarkannya putusan hakim pengadilan. Perlindungan proses hukum (didampingi dari tingkat kepolisian sampai dengan setelah putusan pengadilan), pelayanan psikiater, dan spiritual.

Dalam penelitian ini fokus pada peran Pusat Pelayanan Terpadu Seruni Semarang Jawa Tengah. Ke depannya di harapkan untuk penelitian-penelitian selanjutnya dapat meneruskan apa yang belum di bahas dalam penelitian ini demi kemajuan penelitian keilmuan.

\section{Saran}

Pemerintah Pusat dan Daerah bersama masyarakat merealisasi pembangunan Rumah Perlindungan Sosial Anak (RPSA) untuk menampung dan memberikan pelayanan dan perlindungan terpadu bagi anak yang membutuhkan perlindungan khusus.

Buku:

\section{DAFTAR PUSTAKA}

Abdussalam dan Adri Desasfuryanto. 2016. Hukum Perlindungan Anak. PTIK : Jakarta.

Abu Huraeroh. 2006. Kekerasan Terhadap Anak, Nuansa. Bandung.

Anonim. 2004. Hak Azasi Perempuan Instrumen Hukum untuk Mewujudkan Keadilan Gender. Yayasan Obor Indonesia. Jakarta.

Arief Gosita. 1989. Hukum Perlindungan Anak. Akademika Pressindo. Jakarta.

Didik M. Arief Mansur dan Elisatris Gultom. 2008. Urgensi Perlindungan Korban Kejahatan. PT Raja Grafindo. Jakarta.

Elli Nur Hayati. 2000. Panduan untuk Pendamping Perempuan Korban Kekerasan (Konseling Berwawasan Gender). Pustaka Pelajar. Yogyakarta.

Erika. 2004. Perlindungan Hukum Terhadap Anak Dalam Kasus Kekerasan yang Dialami Oleh Anak ditinjau Dari Undang-Undang Nomor 23 Tahun 2002 tentang Perlindungan Anak. UNIKAAtmajaya. Jakarta.

Ira Dwiati. 2007. Perlindungan Hukum Terhadap Korban Tindak Pidana Perkosaan Dalam Peradilan Pidana. Semarang. (Tesis, Pascasarjana Magister IImu Hukum Undip).

Lilik Mulyadi. 2008. Bunga Rampai Hukum Pidana Dalam Perspektis Teoritis dan Praktek. PT. Alumni : Bandung,

Maidin Gultom. 2006. Perlindungan Hukum Terhadap Anak (Dalam Sistem Peradilan Pidana Anak di Indonesia). Refika Aditama. Bandung.

Rena Yulia. 2010. Viktimologi : Perlindungan Hukum Terhadap Korban Kejahatan, Graha IImu. Yogayakarta.

Rika Saraswati. 2006. Perempuan dan Penyelesaian Kekerasan Dalam Rumah Tangga. Citra Aditya. Bandung.

Skripsi Ida Musofiana, Perlindungan Hukum Bagi Anak Korban Tindak Pidana (Studi Kasus di Polrestbes Semarang). 2015. FH Unissula Semarang.

Sugihastuti. 2007. Teori Apresiasi Sastra. Yogyakarta. Pustaka Pelajar.

Undang-Undang Nomor 23 Tahun 2002 tentang Perlindungan Anak.

Undang-Undang Nomor 23 Tahun 2004 tentang Penghapusan Kekerasan Dalam Rumah Tangga. 
Undang-Undang Nomor 13 Tahun 2006 tentang Perlindungan Saksi dan Korban.

Undang-undang Nomor 35 Tahun 2014 tentang Perubahan Atas Undang-Undang Nomor 23

Tahun 2002 tentang Perlindungan Anak.

http://download. portalgaruda.org/article. php?article=110882\&val=4136

http://pptseruni.blogspot.com/2012/08/profil-ppt-seruni-kota-semarang.html. 